\title{
HUBUNGAN POLA ASUH DEMOKRATIS DENGAN PERKEMBANGAN BAHASA PADA ANAK PRASEKOLAH DI TK NEGERI TABANAN DI KERAMBITAN
}

\author{
Made Kristina Mulyani ${ }^{1,2}$, N. M.A Sukmandari ${ }^{1,2}$, Si Putu Agung Ayu Pertiwi Dewi ${ }^{1,2}$ \\ ${ }^{1}$ Program Studi S1 Keperawatan, ${ }^{2}$ STIKES Bina Usada Bali \\ Korespodensi penulis: arisukmandarimd@gmail.com
}

\begin{abstract}
Abstrak
Latar belakang dan tujuan: Selama anak prasekolah anak mengalami perkembangan kemampuan bahasa dengan sangat cepat yang menjadi landasan untuk perkembangan selanjutnya. Perkembangan bahasa dipengaruhi oleh berbagai faktor diantaranya pola asuh demokratis orang tua. Penelitian ini bertujuan untuk mengetahui pola asuh demokratis terhadap perkembangan bahasa anak prasekolah di Taman Kanak-Kanak Tabanan Kerambitan.

Metode: Penelitian ini merupakan penelitian deskriptif korelasional dengan pendekatan cross sectional. Pola asuh demokratis diukur menggunakan kuesioner parenting dan pengembangan bahasa dengan Denver Developmental Screening Test II. Responden yang dianalisis adalah siswa TK di Tabanan Kerambitan yang diambil dengan teknik total sampling. Hasil penelitian diperoleh pola asuh cukup demokratis sebanyak 32 orang (64\%) dan perkembangan bahasa sebagian besar masuk dalam kategori normal $(96.0 \%)$.

Hasil: Hasil uji korelasi dengan uji Spearman Rho menunjukkan $p=0,018$ dan $r=0,332$. Artinya terdapat korelasi yang signifikan antara pola asuh dengan perkembangan bahasa dan memiliki korelasi positif yang cukup kuat.

Simpulan: ada hubungan pola asuh demokratis dengan perkembangan bahasa pada anak prasekolah di TK Negeri Tabanan di Kerambitan. Disarankan untuk meningkatkan pemahaman tentang pola asuh demokratis dan perkembangan bahasa pada anak, melakukan upaya inovatif dalam menerapkan pola asuh demokratis sesuai dengan perkembangan anak, pengaruh lingkungan dan perkembangan teknologi.
\end{abstract}

Kata kunci: Pola asuh demokratis, Perkembangan bahasa, Anak prasekolah

\section{Pendahuluan}

Anak usia pra sekolah adalah anak yang akan menginjak masa sekolah dengan rentang umur tiga hingga enam tahun (Izzaty, 2017). Pada usia prasekolah, anak akan mengikuti program pada kelompok bermain (usia 3 tahun) dan program taman kanak kanak (usia 4-6 tahun) (Mendiknas, 2009). Anak prasekolah memiliki masa keemasan (the golden age) dalam berbagai aspek perkembangan serta terjadinya pematangan fungsi-fungsi fisik dan psikis sehingga siap merespon dari berbagai aktivitas yang terjadi di lingkunganya (Mulyasa, 2012). Banyak perkembangan terjadi pada masa prasekolah.
Perkembangan bahasa paling cepat terjadi antara 2,5 sampai 5 tahun dan perkembangan bahasa pada masa prasekolah lebih kompleks. Pada usia prasekolah, perbendaharaan kata bertambah dari 50-160 kata menjadi 2000 atau lebih. Susunan kalimat meningkat dari telegrafi kalimat sampai penggabungan semua aturan tata bahasa pokok (Joni, 2015). Baik kemampuan kognitif maupun lingkungan terutama model peran yang konsisten, mempengaruhi perbendaharaan kata, percakapan dan pemahaman Laju perkembangan bahasa anak pada usia prasekolah bervariasi dari satu anak dengan anak lain (Vasilyeva \& Hedges, 
2011). Kemahiran bahasa ini sangat dipengaruhi oleh faktor internal maupun lingkungan meliputi: riwayat keluarga, lingkungan verbal, pendidikan orang tua, jumlah anak dan pola asuh orang tua (Anggraini, 2017). Setiap anak dapat terstimulasi perkembangannya secara optimal jika lingkungan dan orang terdekat menstimulasi dengan bahasa yang dimengerti anak. Salah satu lingkungan yang membawa pengaruh terhadap perkembangan bahasa anak adalah pengasuhan orang tua. Pola asuh orang tua merupakan pola perilaku yang diterapkan pada anak bersifat relatif konsisten dari waktu ke waktu. Pola perilaku ini dirasakan oleh anak, dari segi negatif maupun positif (Tridhonanto, 2014). Pola pengasuhan orang tua di dalam keluarga menentukan perkembangan anaknya. Pola asuh orang tua yang diterapkan pada anak dapat berupa pola asuh otoriter, pola asuh demokratis, pola asuh permisif memanjakan dan pola asuh permisif penelantaran (Adawiah, 2017 dan Adriana D, 2011)

Pola Asuh demokratis adalah sikap orang tua dalam memberikan pendidikan pada anak usia dini dengan cara memberikan kesempatan pada anak untuk membuat pilihan yang disukainya. Orang tua percaya akan kemampuan mereka dalam memandu anak, tetapi juga menghargai keputusan mandiri, minat, pendapat, dan kepribadian anak (Adriana D, 2011). Dalam pola asuh demokratis akan ada interaksi dan komunikasi antara anak dan orang tua. Dalam interaksi tersebut, anak akan menerima contoh kata, bahasa, gaya berbicara dari orang tuanya dan aka nada dorongan dan kesempatan bagi anak untuk mengekspresikan perasaannya melalui katakata sehingga kemampuan berbicara dapat terus dilatih dan ditingkatkan (Mulqiah et al., 2017). Hal tersebut membuat pola asuh demokratis dapat mendukung perkembangan bahasa pada anak.

Studi pendahuluan yang dilakukan pada PAUD dan TK Negeri Kerambitan Tabanan terdapat variasi cara pengasuhan orang tua dan variasi perkembangan bahasa pada anak. Wawancara yang dilakukan tehadap 10 orang tua (ibu) para ibu mengasuh anaknya dengan cara dan pola asuh yang berbeda-beda dengan mayoritas menggunakan pola asuh demokratis. Dari pengkajian kemampuan bahasa dengan menggunakan DDST terhadap 15 orang anak, didapatkan 2 anak mengalami keterlambatan (suspect) dan 13 anak termasuk katagori normal. Dari data tersebut besar kemungkinan terdapat hubungan antara pola asuh orang tua dengan perkembangan bahasa pada anak prasekolah

Penelitian ini bertujuan untuk mengetahui hubungan pola asuh demokratis dengan perkembangan bahasa pada anak prasekolah.

\section{Metode Penelitian}

Penelitian ini termasuk dalam penelitian deskriptif analitik korelasional karena fenomena data variabel yang diamati (pola asuh orang tua dan perkembangan bahasa anak prasekolah) hanya dideskripsikan kemudian dihubungkan (dikorelasikan) tanpa adanya perlakuan pada responden penelitian. Peneliti menggunakan rancangan cross sectional dimana data variabel independen (pola asuh orang tua) dan variable dependent (perkembangan bahasa anak prasekolah) pada responden penelitian diambil dan dikorelasikan dalam waktu yang bersamaan.

Sampel diambil sebanyak 50 responden yang terdiri dari orang tua dan anak dengan cara total sampling. Data dianalisis menggunakan uji korelasi non parametric Rank Spearman.

\section{Hasil dan Pembahasan}

a. Karakteristik responden

Tabel 1 menunjukkan umur responden penelitian minimal 60 bulan dan maksimal 72 bulan dengan rerata 64,9 bulan. Tabel 2 menunjukkan bahwa sebagian besar responden penelitian berjenis kelamin perempuan yaitu 27 responden $(54,0 \%)$. 
Tabel 1 Karakteristik Responden Berdasarkan Umur

\begin{tabular}{ccccc}
\hline \multicolumn{5}{c}{ Deskripsi Umur (bln) } \\
\hline Jmlh & Min & Maks & Rerata & SB \\
\hline 50 & 60 & 72 & 64,9 & 3,4 \\
\hline
\end{tabular}

Sumber data: Master Tabel, 2019

Tabel 2 Karakteristik Responden Berdasarkan Jenis Kelamin

\begin{tabular}{llll}
\hline Variabel & Deskripsi & f & \% \\
\hline Kelamin & Laki - laki & 23 & 46.0 \\
& Perempuan & 27 & 54.0 \\
\hline & Total & 50 & $\mathbf{1 0 0} \%$
\end{tabular}

Sumber data: Master Tabel, 2019

b. Analisis Variabel Penelitian

Tabel 3 menunjukkan proporsi terbesar katagori pola asuh demokratis berada pada katagori cukup demokratis sebanyak 32 responden (64\%). Tabel 4 menunjukkan perkembangan bahasa pada anak mayoritas berada dalam katagori normal sebanyak 48 responden $(96.0 \%)$.

Tabel 3 Deskripsi Pola Asuh Demokratis

\begin{tabular}{lcc}
\hline \multicolumn{1}{c}{ Katagori } & f & \% \\
\hline Kurang demokratis & 10 & 20.0 \\
\hline Cukup demokratis & 32 & 64.0 \\
\hline Sangat demokratis & 8 & 16.0 \\
\hline Total & 50 & 100 \\
\hline
\end{tabular}

Sumber data: Master Tabel, 2019

Tabel 4 Perkembangan Bahasa Pada Anak

\begin{tabular}{lcc}
\hline \multicolumn{1}{c}{ Katagori } & f & \% \\
\hline Normal & 48 & 96.0 \\
\hline Suspect & 2 & 4.0 \\
\hline Unstable & - & - \\
\hline Total & 50 & 100 \\
\hline
\end{tabular}

Sumber data: Master Tabel, 2019

c. Analisis Hubungan Pola Asuh Demokratis Dengan Perkembangan Bahasa

Tabel 5 Hubungan Pola Asuh Demokratis Dengan Perkembangan Bahasa

\begin{tabular}{|c|c|c|c|c|c|c|c|c|}
\hline \multirow{3}{*}{\multicolumn{2}{|c|}{ Variabel }} & \multicolumn{6}{|c|}{ Perkembangan Bahasa } & \multirow{3}{*}{ Korelasi } \\
\hline & & \multicolumn{2}{|c|}{ Normal } & \multicolumn{2}{|c|}{ Suspect } & \multicolumn{2}{|c|}{ Unstale } & \\
\hline & & $\mathrm{f}$ & $\%$ & $\mathrm{f}$ & $\%$ & $\mathrm{f}$ & $\%$ & \\
\hline \multirow{3}{*}{$\begin{array}{c}\text { Pola } \\
\text { Asuh } \\
\text { demokr } \\
\text { atis }\end{array}$} & Kurang & 8 & 80 & 2 & 20 & 0 & $\mathrm{O}$ & \multirow{3}{*}{$\begin{array}{l}\mathrm{p}=0,018 \\
\mathrm{r}=0,332\end{array}$} \\
\hline & Cukup & 32 & 100 & $\mathrm{O}$ & $\mathrm{O}$ & 0 & 0 & \\
\hline & Sangat & 8 & 100 & $\mathrm{O}$ & $\mathrm{O}$ & 0 & 0 & \\
\hline
\end{tabular}

Tabel 5 menunjukkan pola asuh cukup demokratis memiliki perkembangan bahasa yang normal sebanyak 32 responden dengan prosentase $100 \%$. Berdasarkan tujuan penelitian yaitu mengidentifikasi hubungan pola asuh demokratis terhadap perkembangan bahasa anak prasekolah di TK Negeri Tabanan di Kerambitam menggunakan uji Spearman Rho didapatkan nilai signifikansinya adalah 0,018 . Jadi nilai signifikansi hitung $(\mathrm{p}=0,018)$ lebih kecil dari nilai signifikansi tabel $(\mathrm{p}<0,05)$. Berarti ada 
hubungan yang signifikan antara pola asuh demokratis terhadap perkembangan bahasa anak prasekolah di TK Negeri Tabanan di Kerambitam. Berdasarkan uji Spearman Rho didapatkan coefficient correlation sebesar 0,332 yang artinya memiliki korelasi positif yang cukup kuat. Dapat disimpulkan ada hubungan yang cukup kuat antara pola asuh demokratis dengan perkembangan bahasa anak prasekolah di TK Negeri Tabanan di Kerambitam. Arah hubungan yang positif berarti semakin demokratis pola asuh maka perkembangan bahasa semakin baik, begitu juga sebaliknya.

\section{Simpulan}

Ada hubungan yang cukup kuat antara pola asuh demokratis dengan perkembangan bahasa anak prasekolah di TK Negeri Tabanan di Kerambitan.

\section{Referensi}

Adawiah, R. (2017). Pola Asuh Orang Tua Dan Implikasinya Terhadap Pendidikan Anak. Jurnal Pendidikan Kewarganegaraan, 7(1), 33-48.

Anggraini, Ni Putu Ayu Ari. (2018). Hubungan Pola Asuh Orang Tua Dengan Kemadirian Anak Usia 5-6 Tahun Di Tk Tunas Bangsa Wiyono Pesawaran. Laporan Skripsi. Universitas Lampung.

Adriana D. (2011). Tumbuh Kembang \& Terapi Bermain Pada Anak. Jakarta: Salemba Medika

Izzaty, R. E. (2017). Perilaku Anak Prasekolah. Jakarta: PT Elex Media Komputindo.

Joni. (2015). Hubungan Pola Asuh Orang Tua Terhadap Perkembangan Bahasa Anak Prasekolah (3-5 Tahun) Di Paud Al-Hasanah. 1(6), 42-48.

Madyawati, L. (2016). Strategi Pengembangan Bahasa pada Anak. Jakarta: Kencana.

Mendiknas. (2009). Peraturan Menteri Pendidikan Nasional Republik Indonesia Nomor 58 Tahun 2009
Tentang Standar Pendidikan Anak

Usia Dini. Retrieved from http://simpuh.kemenag.go.id/regulasi /permendiknas_58_09.pdf

Mulqiah, Z., Santi, E., \& Lestari, D. R. (2017). Pola Asuh Orang Tua Dengan Perkembangan Bahasa Anak Prasekolah ( Usia 3-6 Tahun ). 5, 61-67.

Mulyasa. (2012). Manajemen PAUD. Bandung: Rosda Karya

Noorlaila, I. (2010). Panduan Lengkap Mengajar PAUD. Yogyakarta: Pinus Book Publisher.

Pietono, Y. D. (2014). Mendidik Anak Sepenuh Hati. Jakarta: PT Elex Media Komputindo

Saeful, \& Libertina, A. (2012). Membuat Anak Rajin Belajar Itu Gampan. Jakarta: Visimedia.

Soetjiningsih. (2014). Tumbuh Kembang Anak (Edisi 2). Jakarta.

Tridhonanto. (2014). Pola Asuh Demokratis. Jakarta: PT Elex Media Komputindo.

Vasilyeva, M., \& Hedges, L. V. (2011). NIH Public Access. 61(4), 343-365. https://doi.org/10.1016/j.cogpsych.20 10.08.002.Sources. 